\title{
HUMAN GENETICS AS AN APPROACH TO THE CLASSIFICATION OF MENTAL DISEASES
}

\author{
Aníbal Silveira *
}

Since 1932, we have experienced steadily growing difficulty in entering several mental diseases properly into Brazilian classification. Among such patterns, there is, for instance, the "chronical hallucinatory delusion" isolated by Roxo, which is paraphrenia-like, but not at all paraphrenia in the classical meaning, and far more common than this very condition. Listing both entities under the same heading, as followed by our national system, resulted in undue overcharge for the proper rubric in Brazilian statistics. Other atypical patterns such as the "mixed psychoses" 4 , could not find a place in our system and had to be forced into the place reserved for one of the principal conditions at play in the given instance. If psychiatrists task were to be construted as one of labeling patients, this handicap would not matter, but no reasonable person would foster such views. The difficulties were still more upsetting when we got acquainted with the several atypical endogenous psychoses described by Kleist ${ }^{8}$. Here, the heredological factors are even more complex than in any other mental diseases quoted above. By reviewing the world literature in psychiatry, one becomes aware the tremendous source of error that comes from the overlooking of Kleit's set of psychoses. In our mind, the appreciations of clinical diagnosis, of shock therapies, and more recently the outcome of leucotomy, reflect how badly needed is a stable ground for clinical diagnosis of mental diseases. Several papers have shown it from many angles $3,6,12,18,24$. Looking on the classifications current in foreign countries, we found the same lack of room for such atypical psychoses of endogenous predispositional background. In addition, it was apparent that no uniform and simple criterion could be used by their authors to afford a systematic arrangement for the different entries. Everybody feels impossible, indeed, to ordinate all the known psychoses according to any anatomical standpoint, or to etiological factors or even regarding their clinical outcome. As a result, the many elassifications in honor abroad diverge from each other only in the measure that one or another point of view is preferred for a given group of psychoses: in general, the social and eugenical aspects of psychiatry are left aside in

Presented at the International Congress of Psychiatry (Paris, September-150).

* Chief of Staff, Juqueri State Hospital, São Paulo - Brasil, Lecturer in Psychiatry, University of São Paulo Faculty of Medicine.

Nota da Redação - Este trabalho é publicado em língua inglêsa porque assim foi apresentado no Congresso Internacional de Psiquiatria reunido em Paris. 
most of them, since they assemble under one same heading psychoses that behave in a quite different manner as far as heredological meaning is concerned $^{2,15,17,19,22}$.

With such considerations in mind, we tried to find out a consistent classification of mental conditions as we were called to send out suggestions for a revision of the Brazilian classification in 1944. Three points set our reasoning: 1) the clinical outcome of psychoses as seen in longitudional section, so to speak; 2) the general features of the psychoses as a group, as seen in the daily practice, that is, from the practicioner's point of view; 3 ) the hereditary significance of the individual psychoses, that is, their implication for the descendants of the patients. The latter data were to be derived from the available tables of "empirical heredoprognosis" 1, 2, 5, 7, 14, 20 and principally from the heredological researches carried out accord. ing to the precision method for differentiation of patterns, employed by Kleist and co-workers $3,8,9,10^{\circ}, 11,13,17,21$.

Combining these views and diverging in many points from the proposed revision, so to approximate it to the general patterns of classification followed in our national systematics, we arrived at a tentative substitute ${ }^{22}$, in which we tried to avoid doctrinal elaborations, limiting ourselves to dispose its headings in regard to "eugenic profilaxis". Some years later, in 1948, it was possible to set farther the combination of eugenical and dynamic criteria, since we had the original Brazilian classification for starting point. This enabled us to include a few mental conditions not considered in other systems and at the same time to separate in a more definite manner the endogenous illnesses and the casual patterns simulating them. The psychoses, 24 in number, entered there into 5 major groups, arranged according to the intensity of endogenous taint implied by them ${ }^{23}$. However, as we managed to ascertain through hospital practice the proper order of the individual headings, some changes of position were found necessary, yet keeping every item under its previous main group. Such rearrangement is presented in this paper (table I).

Since, as accepted by everyone, psychiatry is above all aimed at mental hygiene and the eugenical problems related to prevention of mental diseases, we selected heredobiology for the leading principle of our tentative classification. Accordingly, the several mental diseases fell under 5 sections, as regards the possible transmission of morbid trends: 1) Mental patterns with endogenous background not always demonstrated, or in which it is responsible for "pathoplastic" traits only, not by necessity for the precipitating effect; 2) Conditions with definite heredological charge, even when they do not come to light spontaneously, and in which it is sometimes hard to ascertain the role played by external causes as faced to the inner morbid forces; 3) Constitutional diseases, in which hereditary tendency in unquestionable and is such as to cause the breakdown without any interfering factor; 4) Mental conditions, not always psychotic in feature, in regard to which hereditary charge is so diluted or inconsistent that it may not be 
noticed at first sight and has to be looked for, often in terms of abnormal personality traits only; 5) Defective mental patterns, in which the genetic factor reflects on the sensitivity of cerebral systems to injuries and is responsible for their functional decay as well as for their selective anatomical deterioration.

On the other hand, trying to check the above groups against the environmental or the somatogenic factors at play, we may find that these latter decrease in precision or in effectiveness as we proceed from the extreme units toward the central one, here called III, which represents the climax of heredological trends. Thus, the toxi-infectious diseases with mental illness as a group, show more definite mechanisms of action than the psychoses by intoxication listed under II. About in the same way, factors that precipitate the mental patterns shift from predispositional, psychological and situational in group IV, to overtly structural in the last group, here in terms of brain lesions focal and then diffuse. Using the same criterion for ranking of the differents patterns within each major group, the order of the former emerges naturally. For instance, General Paralysis and toxiinfectious psychoses in general should represent the two extremes of group I, the latter being close to psychosis by accidental intoxication in the second group; within unit $\mathrm{V}$, systemic abiotrophic diseases as Alzheimer's and Pick's were to be a bound opposite to mental deficit by general encephalopathy. As for the endogenous sets, constitutional and marginal, we have a comparable disposition for the individual conditions: from epilepsy to paranoia there is a curve with its acme in schizophrenia as the endogenous charge shows itself more consistent and obvious and the abnormal condition more permanent; in addition, oligophrenia representing a different kind of heredological transmission and mixed psychoses pointing to the interaction of more than one heredological circle, fall near to the fourth main group. In this one all of the entries, listed under 14 to 20 , involve the inheritance of abnormal trends as a background: for the first type we have the combination of diverging morbid circles and for the next two the appearance respectively of abnormal but consistent set of traits and of isolated dysgenic trends; there come next two mental conditions in which underlying trends are brought to light by psychogenic or situational factors, and following two further ones in which the intervening moment is more structural, cerebral in character.

In the above clinical conditions, it is easy to see, the efficiency of therapeutic measures runs in parallel with the exogenous factors, with the exception of neurotic and psychogenic conditions as well as the typical and marginal "functional" psychoses, recoveries in these latter ones being only transitory or phasic.

We represented the three above criteria in figure 1 , where reversibility, exogenous and endogenous factors are plotted for each individual entry of table I. The ratings were all empirical, since statistical evaluation has not been achieved as yet. However, it seems that such rough appreciation 
may support our hope for a rational classification of mental diseases in terms of a "natural series" in the light of human genetics.

TABLE I

I - Psychoses reith toxi-infectious diseases: 1 - Diffuse syphilitic meningoencephalitis (G.P.); 2 - Neuro-syphilis in general; 3 - Epidemic neuraxitis; 4 - Psychoses with infectious diseases, in general.

II - Psychoses with accidental intoxications: 5 - Psychosis due to accidental intoxication; 6 - Psychosis due to auto-intoxication (endocrine or metabolic).

III - Constitutional endogenous psychoses: 7 - Epilepsy proper; 8 - Maniac-depressive psychosis; 9 - Schizophrenia; 10 - Paraphrenia; 11 - Paranoia; 12 - Oligophrenia proper (endogenous); 13 - Mixed and combined psychoses.

IV - Marginal endogenous states: 14 - Autocthonous atypical degenerative psychosis (Kleist); 15 - Psychopathic personality; 16 - Drug addiction; 17 Neurosis; 18 - Reactive psychosis; 19 - Symptomatic seizures; 20 - Chronic hallucinatory delusion.

V - Defective states by local or abiotrophic brain lesions: 21 - Alzheimer's and Pick's diseases; cerebral arteriosclerosis: 22 - Senile dementia proper; 23 Brain focal lesions in general; 24 - Mental deficit by encephalopathy, not endogenous.

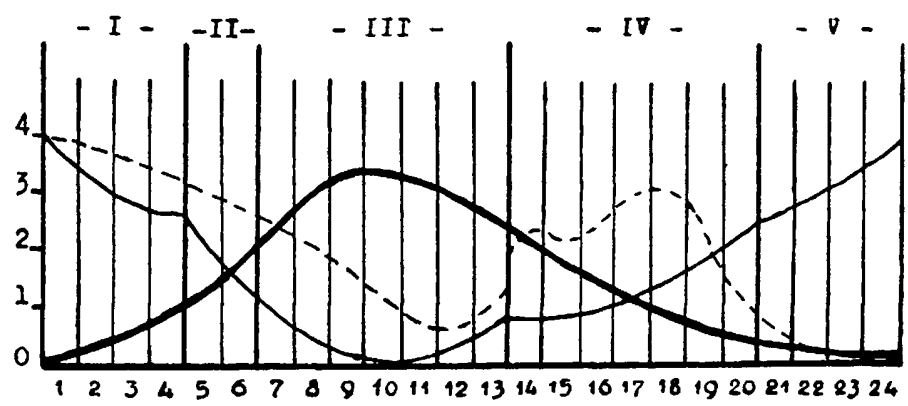

Fig. 1

endogenous factors: 3, overtly constitutional; 2, latent, as predisposition; 1, demonstrable but not obvious.

exogenous components, environniental and/or somatogenic: 3, necessary and brain determined, toxic or structural; 2, indirect; 1, occasional.

- - - reversibility, spontaneous or therapeutic: 4, permanent, rather prompt; 3, permanent but slow; 2, partial or temporary; 1, doubtful.

\section{SUMMARY}

If we try to arrange the many patterns of mental disease as regards the underlying heredological trends it is possible to develop a system 
disposed as a "natural series". In our tentative one, which combines eugenic and dynamic criteria chiefly, we tried to assemble 24 separate clinical conditions into 5 major groups: I - Psychoses with toxi-infectious diseases (4 entries); II - Psychoses with accidental intoxications (2 entries); III - Constitutional endogenous psychoses ( 7 entries); IV Marginal endogenous states (7 entries); $\mathrm{V}-$ Defective states by local or abiotrophic brain lesions (4 entries). Among the conditions listed under IV are Kleist's marginal or "degenerative" psychoses, which are frequent indeed in psychiatric practice, so to require their consideration.

\section{RESUME}

Si l'on ordonne les diverses formes de maladies mentale d'après les facteurs hérédologiques sousjacents il en resulte une vraie "série naturelle". Nous avons essayé une classification combinant surtout les caractères eugénique et dynamique, y faisant rentrer 24 conditions cliniques diverses, rangées dans 5 groupes principaux: I - Psychoses par maladie toxi-infectieuse (4 rubriques); II - Psychoses par intoxication accidentale (2 rubriques); III - Psychoses endogènes constitutionnelles ( 7 rubriques); IV - Etats endogènes marginaux (7 rubriques); V Etats déficitaires par lésions cérébrales en foyer ou abiotrophiques (4 rubriques). Parmi les conditions sous IV se trouvent les psychoses marginales "dégéneratives" de Kleist, dont la fréquence dans la pratique psychiatrique journalière leur assure une place individuelle dans le classement.

\section{RESUMO}

Dispondo as diferentes formas de doença mental de acôrdo com os fatôres heredológicos subjacentes obtém-se uma verdadeira "série natural". A classificação que procuramos estabelecer combina os critérios eugênico e dinâmico principalmente e consta de 24 quadros clínicos distintos, reunidos em 5 grupos fundamentais: I - Psicoses de origem infecciosa predominante (4 rubricas); II - Psicoses de origem tóxica predominante (2 rubricas); III -- Psicoses endógenas constitucionais (7 rubricas); IV Quadros endógenos marginais (7 rubricas); V - Quadros deficitários por lesões focais ou abiotróficas do cérebro (4 rubricas). Entre as condiçóes clínicas do grupo IV encontram-se as psicoses marginais "degenerativas" de Kleist, cuja freqüência na psiquiatria cotidiana lhes assegura lugar individualizado na. classificação.

\section{REFERENCES}

1. Barahona Fernandes, H. J. - Hereditariedade e profilaxia eugênica das doenças mentais. Impr. Méd. (Lisboa), 7:1-25, 1941.

2. Conrad, K. - Erbanlage und Epilepsie. Ztschr. f. Neurol., 159:521, 1937.

3. Fünfgeld, E. - Die Motilitätspsychosen und Verwirrtheiten. Karger, Berlin, 1936. 
4. Gaupp, R. u. Mauz, F. - Krankheitseinheit und Mischpsychosen. Ztschr. f. Neurol., $101: 1-44,1926$.

5. Gerum, K. - Beitrag zur Frage der Erbbiologie der genuinen Epilepsie, der epileptoiden Erkrankungen und der epileptoiden Psychopathien. Ztschr. f. Neurol., 115:319-422, 1928.

6. Hoch, P. a. Rachlin, H. L. - An evaluation of manic-depressive psychosis in the light of follow-up studies. Amer. J. Psychiat., 97:831, 1941.

7. Kallmann, F. J. - The genetics of psychoses. An analysis of 1,232 twin index families. Report Congr. Internat. Psychiatrie (Paris), 6:1-40, 1950.

8. Kleist, K. - a) Über zykloide, paranoide und epileptoide Psychosen und über die Frage der Degenerationspsychosen. Schweiz. A rci. f. Neurol. u. Psychiat., 23:3-37, 1928. b) Fortschr. d. Psychiatrie (Frankfurt) Kramer, 1947.

9. Kleist, K. u. Driest, W. - Die Katatonien auf Grund katamnesticher Untersuchungen (I 'T'eil). Ztschr. f. Neurol., 157:479-556, 1937.

10. Kleist, K., Leonhard, K. u. Schwab, H. - Die Katatonien auf Grund katamnesticher Untersuchungen (11 I T'eil) Ztschr. f. Neurol., 168:535-586, 1940.

11. Kleist, K. u. Schwab, H. - Die verworrenen Schizophrenien auf Grund katamnestischer Untersuchungen. A rch. f. Psychiat. u. Ztschr. f. Neurol,, 184: $28-79,1950$.

12. Langfeldt, $G$. - Zur Frage der spontanen Remissionen der schizophreniformen Psychosen mit besonderer Berichtsichtigung der Frage nach der Dauer dieser Remissionem. Ztschr. f. Neurol., 164:494-500, 1939.

13. Leonhard, K. - Atypische endogene Psychosen im Lichte der Farnilienforschung. 'Ltschr. f. Neurol., 149:520, 1934.

14. Luxenburger, H. - Eugenische Prophylaxe. In Bleuler, E. - Lehrbuch der Psychiatrie, Springer, Berlin, 1937.

15. Meyer, A. - Genetisch-dynamische Psychologie versus Nosologie. 'Ztschr. f. Neurol., $101: 406-427,1926$.

16. Meyer, G., Leonhard, K. u. Kleist, K. - Die paranoiden Schizophrenien auf Grund katamnestischer Untersuchungen. 'Ltschr. f. Neurol., 177:114-172, 1944.

17. Neele, E. -- Die phasischen Psychosen nach ihrem Erscheinungs und Erbbild. Barth, Leipzig, 1949.

18. Panse, F. - Lur Frage der Auslösung endogener Psychosen durch akute Infektionen. Arch. f. Psychiat. u. Ztschr. f. Neurol., 182:1, 1949.

19. Pedersen, A., Port, R. a. Schou, H. I. - Periodical depression as an independent nosological unit. Acta Psychiat. et Neurol,, 23:285, 1948.

20. Rüdin, E. - Vererbung und Entstehung geistiger Störungen. Springer, Berlin, 1916.

21. Schwab, H. - Die Katatonien anf Grund katamnestischer Untersuchungen (II Teil). Ztschr. f. Neurol., 163:441-506, 1938.

22. Silveira, A. - A classificação nacional das doenças mentais. Arq. Assist. Psicopatas (São Paulo), 9:73-106, 1944.

23. Silveira, A. - $O$ aspecto heredológico na classificação das doenças mentais. A rq. Assist. Psicopatas (São Paulo), 13:79-81, 1949.

24. Smith, J. Chr. - Atypical psychoses and heterologous hereditary traits. J. Nerv. a. Ment. Dis., 62:1-32, 1925.

Hospital de Juqueri, Franco da Rocha - Estado de São Paulo. 